\title{
A review of experimental studies on sand screen selection for unconsolidated sandstone reservoirs
}

\author{
Nur Aqilah Ahad ${ }^{1} \cdot$ Morteza Jami $^{1}$ (1) $\cdot$ Stephen Tyson ${ }^{1}$
}

Received: 16 September 2019 / Accepted: 23 December 2019 / Published online: 2 January 2020

(c) The Author(s) 2020

\begin{abstract}
Sand production is a problem that affects hydrocarbon production from unconsolidated sandstone reservoirs. Several factors, such as the strength of the reservoir, its lithification and cementation and reduction in pore pressure, may cause sand to be separated from the rock and transported by hydrocarbons to the well. Producing sand commonly causes erosion and corrosion of downhole and surface equipment, leading to production interruptions and sometimes forces operators to shut-in wells. Several different methods of sand control are available to reduce the impact of sand production. The reviewed papers suggest that the most suitable methods for unconsolidated sandstone reservoirs are stand-alone screens and gravel packs. Because of the cost and complexity of gravel packs, stand-alone screens are usually the first choice. These screens have different geometries, and selection of the most suitable screen depends on the particle size distribution of the grains in the formation and other reservoir and production parameters. A screen retention test, run in a laboratory with screen samples and typical sands, is often used to ensure that the screen is suitable for the reservoir. This paper reviews the main causes of sand production, the properties of unconsolidated sandstones that predispose reservoirs to sand production problems and the selection criteria for the most suitable mitigation method. The process of selecting a screen using experimental screen retention tests is reviewed, and the limitations of these tests are also discussed. Some numerical simulations of experimental tests are also reviewed, since this represents a very cost-effective alternative to laboratory experiments.
\end{abstract}

Keywords Sand production · Fine production $\cdot$ Sand control $\cdot$ Well screen $\cdot$ Stand-alone screen $\cdot$ Sand retention test

\section{Introduction}

Sand production affects more than $70 \%$ of the oil and gas reservoirs around the world (Khamehchi et al. 2015; Ikporo and Sylvester 2015). It can have a severe effect on well productivity and equipment as it could plug the well and erode equipment which could lead to loss of containment and also settle in surface vessels. Sand production can be controlled and mitigated by installing sand control both downhole and at the surface. The application of sand control in a reservoir could prevent or minimize the sand from being produced. However, installing unsuitable sand control normally comes with risks, such as high skin and a decrease in productivity index (Hodge et al. 2002; Khamehchi et al. 2015; Ikporo

Morteza Jami

morteza.jami@utb.edu.bn

1 School of Petroleum and Chemical Engineering, Universiti Teknologi Brunei, Bandar Seri Begawan, Brunei Darussalam and Sylvester 2015; Changyin et al. 2016; Gupta et al. 2016; Toelsie and Prediepkoemar 2013; Matanovic et al. 2012).

In considering sand control methods, one must differentiate between load-bearing solids and fine particles (fines), where it is actually beneficial to produce fines as long as they can move freely through the screen or gravel packs and not plug it. Sand control usually refers to the control of the loadbearing solids that support the overburden. The critical factor in assessing the risk of sand production is the ability to maintain the sand production below an acceptable rate, and at flow rates which will make the well production acceptable. The aim of this paper is to review the experimental studies on various sand screens to mitigate sand production in unconsolidated reservoirs (Ikporo and Sylvester 2015; King 2013; Hodge et al. 2002; Khamehchi et al. 2015).

\section{Causes of sand production}

Sand production generally occurs when the reservoir sandstone cement is weak and fails under in situ stress or

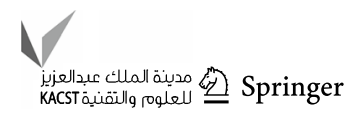


imposed stress, where both stresses were changed during hydrocarbon production. The produced oil or gas from such reservoirs can create problems ranging from erosion of the downhole or surface facilities to well stability and later produced sand disposal. Sand production can occur both naturally, in unconsolidated formations, or due to drilling and production activities.

In completely unconsolidated formations, sand production may happen at the start of the fluid flow from the formation due to drag from the fluid or gas turbulence, which detaches sand grains and carries them to the perforation. It also can start when there are changes in the production rate, water breakthrough or changes in the gas-liquid ratio (Deghani 2010; Ikporo and Sylvester 2015; Toelsie and Prediepkoemar 2013).

Sand production can lead to one or more of the following problems:

- Formation damage or collapse by the flowing sand grains

- Wellbore instability

- Casing collapse

- Impairment or failure of downhole and surface equipment

- Lost production time due to well shut-in to change damage equipment or clean the sand filled wellbore

- Work-overtime and expense to service the well and production equipment

- Coiled tubing cost and possible complications

- Cost of separating sand from the produced fluid

- Environmental problems in the disposal of the produced contaminated sand.

When sand and hydrocarbon are produced at the surface with a given flow rate, it creates downhole reservoir cavitation, and over time the formation may collapse due to lack of support which may result in a complete loss of productivity. The formation collapse leads to a significant pressure drop near the wellbore. When sand production occurs, the sand grains will accumulate behind the casing to create a lower permeability zone, especially for formations with a high clay content or a wide range of sand grain sizes. Sandstones with narrow grain size distributions show lower variations in permeability. The five main factors affecting the sand production are: the degree of consolidation, reduction in pore pressure, production rate, reservoir fluid viscosity and increasing water production throughout the life of the well (Ikporo and Sylvester 2015; Deghani 2010; Khamehchi et al. 2015).

\section{Degree of consolidation}

The degree of consolidation defines how strong the individual sand grains have been bound together and how the cementation process has developed. Typically, the compaction and cementation of sandstone is a secondary geological or diagenetic process. Older sediments and particular lithologies tend to be more consolidated. For this reason, most shallow, geologically younger reservoirs are associated with sand production, as they often have weak cementation that binds the sand grains together. Compressive rock strength is a geomechanical property of rock that is related to the degree of consolidation. Unconsolidated formations usually have a compressive strength of less than 1000 psi or about 6.89 MPa (Ikporo and Sylvester 2015; Wan and Wang 2004; Ikporo and Sylvester 2015; Toelsie and Prediepkoemar 2013; Penberthy and Shaughnessy 1992; Roberts 2014; Suman et al. 1991).

\section{Reduction in pore pressure throughout the life of a well}

Part of the weight of the overlying rocks is supported by the pore pressure in the reservoir. Upon producing hydrocarbon, the pore pressure drops and some of the support is removed. This creates an increased amount of stress on the reservoir to the point where the sand grains may break loose from the matrix and create fines that are produced along with fluids (Penberthy and Shaughnessy 1992; Roberts 2014; Suman et al. 1991; Toelsie and Prediepkoemar 2013).

\section{Production rate}

The production of reservoir fluids creates pressure differential and frictional drag forces that could exceed the formation compressive strength when those two forces are combined. This suggests that there is a critical flow rate, a rate when the combined forces are great enough to exceed the formation compressive strength for the sand production to happen. This critical flow rate may be determined by slowly increasing the production rate until sand production is detected. In many cases, the critical flow rates are usually found to be below the acceptable production rate for the well (Khamehchi and Reisi 2015; Khamehchi et al. 2015; Ikporo and Sylvester 2015; Penberthy and Shaughnessy 1992; Roberts 2014; Suman et al. 1991; Toelsie and Prediepkoemar 2013).

\section{Reservoir fluid viscosity}

The frictional drag force created by the flow of reservoir fluid is directly related to the velocity of the fluid flow and viscosity of the reservoir fluid being produced. High fluid viscosity will apply a greater frictional drag force to the formation sand grains and will cause sand to be produced from many heavy oil reservoirs (Ikporo and Sylvester 2015; Penberthy and Shaughnessy 1992; Roberts 2014; Suman et al. 1991; Matanovic et al. 2012; Toelsie and Prediepkoemar 2013; Changyin et al. 2016). 


\section{Increasing water production throughout the life of a well}

Sand production may happen when water enters the well. Water production has a severe impact on the stability of the sand arch around the perforation, which may initiate sand production. Water production can affect the relative permeability in water-wet formations. As more water is produced, the relative permeability of oil decreases and this results in an increase in differential pressure to produce oil at the same production rate. This eventually creates a greater shear force across the formation sand grains and leads to instability of sand arch around each perforation and raises the sand production. Table 1 summarizes the various causes of sand production into three categories: formation, completion and production issues.

Table 1 Parameters influencing sand production (Khamehchi and Reisi 2015)

\begin{tabular}{|c|c|}
\hline Categories & Factors affecting sand production \\
\hline Formation: reservoir properties & $\begin{array}{l}\text { Rock strength } \\
\text { Vertical and horizontal in situ } \\
\text { stresses (change during deple- } \\
\text { tion) } \\
\text { Depth (influences strength, } \\
\text { stresses and pressure) } \\
\text { Pore pressure changes during } \\
\text { reservoir depletion } \\
\text { Permeability } \\
\text { Fluid composition (gas, oil, } \\
\text { water) } \\
\text { Drainage radius } \\
\text { Reservoir thickness } \\
\text { Reservoir heterogeneity }\end{array}$ \\
\hline Completion & $\begin{array}{l}\text { Wellbore orientation } \\
\text { Wellbore diameter } \\
\text { Completion type (openhole, } \\
\text { perforated) } \\
\text { Perforation policy (height, size, } \\
\text { density, phasing, under/over- } \\
\text { balanced). } \\
\text { Sand control (screen gravel pack, } \\
\text { chemical consolidation) } \\
\text { Completion fluids, stimulation } \\
\text { (acid volume, acid type) } \\
\text { Size of tubular }\end{array}$ \\
\hline Production & $\begin{array}{l}\text { Flow rate } \\
\text { Damage (skin) } \\
\text { Bean-up and shut-in policy } \\
\text { Artificial lift technique } \\
\text { Depletion } \\
\text { Cumulative sand volume } \\
\text { Water or gas coning }\end{array}$ \\
\hline
\end{tabular}

\section{Types of sand production}

According to Khamehchi and Reisi (2015), the classification of sand production is considered an essential part of predicting the produced sand rates. This classification has been developed based on field observations to allow for a better comparison and interpretation of sand production.

\section{Transient sand production}

Transient sand production is when the sand concentration is declining with time under constant well production conditions. It is observed during clean-up after perforating or acidizing after bean-up and after water breakthrough.

\section{Continuous sand production}

Sand settles inside the wellbore and increases the hold-up depth. Depending on the sand concentration and the lifting capacity of the fluid flow, the producing interval may eventually be blocked.

\section{Catastrophic sand production}

This happens when the rate of sand produced is high enough to cause the well to suddenly choke and possibly die. It may be due to slugs of sand creating sand bridges of moderate volume in tubing or choke, for example, during or after bean-up and shut-in operations, or when a massive influx of sand fills and obstructs the wellbore.

\section{Sand control methods}

A wide range of sand control methods are available including a variety of different downhole sand screens and gravel packs. However, installing each type of sand control carries risks; thus, it is important to determine the correct sand control method for a particular formation. Ott (2008) summarized various types of sand control methods including; no control, slotted liner, wire-wrapped screen, prepacked screen, shrouded metal mesh screen, expandable screen, in situ consolidation (resin), oriented and selective perforation, openhole gravel pack, frac pack and screenless frac pack.

The main factors in the selection of suitable sand control methods are cost, efficiencies in retaining sand and life span. Table 2 presents the advantages and disadvantages of the available sand control methods.

Among various sand control methods, the screen-only completions are considered the preferred option for the sand control method for unconsolidated formations, as these methods maximize productivity and minimize completion complexity and cost. This is consistent with a new approach 
Table 2 Advantages and disadvantages of conventional sand control methods (King 2013; Parlar et al. 2016)

\begin{tabular}{|c|c|c|}
\hline Sand control method & Advantages & Disadvantages \\
\hline Wire-wrapped screen & $\begin{array}{l}\text { Simplest and cheapest } \\
\text { Most difficult to plug } \\
\text { Best in the lower part of a vertical well } \\
\text { Keystone slot } \\
\text { High manufacturing efficiency } \\
\text { Profile materials can be stainless steel }\end{array}$ & $\begin{array}{l}\text { Easily damaged in running operations } \\
\text { Less resistant to erosion } \\
\text { Inaccurate wire spacing can allow the } \\
\text { production of formation sand or plug } \\
\text { Can be damaged when installing through } \\
\text { doglegs, high angle and horizontal } \\
\text { sections }\end{array}$ \\
\hline $\begin{array}{l}\text { Expandable sand screen (ESS } \\
\text { is also known as conformance } \\
\text { screen) }\end{array}$ & $\begin{array}{l}\text { Easy installation } \\
\text { The expansion provides increased internal diameter for remedial } \\
\text { work } \\
\text { Less chance of hot spots and plugging }\end{array}$ & $\begin{array}{l}\text { Stimulation requires a separate trip } \\
\text { Fluid loss control devices cannot be used } \\
\text { Low collapse rating }\end{array}$ \\
\hline Prepacked screen & $\begin{array}{l}\text { Moderately expensive } \\
\text { Can withstand some erosion } \\
\text { Best in the upper part of the vertical well and in horizontal wells }\end{array}$ & $\begin{array}{l}\text { Easiest to plug } \\
\text { Easily damaged in running operations }\end{array}$ \\
\hline Woven screen or metal mesh & $\begin{array}{l}\text { Can withstand some erosion } \\
\text { Best in the upper part of a vertical wells, horizontal wells and in } \\
\text { bare screen completions }\end{array}$ & $\begin{array}{l}\text { Expensive } \\
\text { Relative easy to plug } \\
\text { Easily damaged in running operations }\end{array}$ \\
\hline Slotted liner & $\begin{array}{l}\text { Not used to control sand production, but to help with borehole } \\
\text { stability } \\
\text { Moderate cost } \\
\text { Easy installation } \\
\text { Good for well-sorted sands } \\
\text { Low skin }\end{array}$ & $\begin{array}{l}\text { Low rotational strength } \\
\text { Low inflow area } \\
\text { Subject to erosion } \\
\text { Low reliability } \\
\text { Easily plugged }\end{array}$ \\
\hline Openhole gravel pack & $\begin{array}{l}\text { Maximum un-fractured contact } \\
\text { High flow in higher permeability formations }\end{array}$ & $\begin{array}{l}\text { More difficult to design or place } \\
\text { Limited application experience } \\
\text { Limited zone or water control } \\
\text { Formation wall is close to the screen }\end{array}$ \\
\hline Cased-hole gravel pack & $\begin{array}{l}\text { A trusted method for deepwater reservoir } \\
\text { Moderate reliability }\end{array}$ & $\begin{array}{l}\text { High cost of installation and replacement } \\
\text { Low inflow area } \\
\text { Subject to erosion } \\
\text { Low reliability } \\
\text { Easily plugged }\end{array}$ \\
\hline
\end{tabular}

by Parlar et al. (2016), which suggests that to select sand control options, one should start with the simplest and most cost-effective sand control, and move to select the complex and expensive options if the simple ones do not meet the design criteria for the project. A stand-alone screen is usually the first choice for completing an openhole completion that is prone to sand production (Hodge et al. 2002).

Parlar et al. (2016) have also listed technical factors required for selecting a completion technique:

- Particle size distributions (PSDs) of sand samples from various depth

- Lithological changes (shales, silts, clean/dirty sand) along the planned well path

- Rock strength

- Economic and risk analysis including the cost of installation and cost of failure

- Risks involved in well execution and through the life of wells.

- Tolerance to solids production considering surface facilities, disposal and erosion issues
- Type of well (producer or injector)

- Type of fluids (oil or gas for producers, seawater, produces water or gas for injectors, cycled injection and production as in underground gas-storage wells) rates

- Zonal-isolation requirements

- Inflow control valve (ICV) requirements

- Logistics (rig space and location)

\section{Stand-alone screen (SAS)}

Stand-alone sand screens are the lowest cost sand control option. They are highly reliable and simple and give long-term productivity performance. SAS is the preferred option for highly deviated or horizontal openhole completions. One of the key parameters for SAS is the sand retaining precision, which determines the success of sand control and whether high production rates can be achieved. The objective of SAS selection is to identify screens that effectively retain sands while maximizing hydrocarbon production, by choosing optimal sand screen 
aperture and evaluating the limitations during sand retention tests (Wu et al. 2016; Changyin et al. 2016).

There are different types of stand-alone sand screens (Fig. 1). The common types are:

1. Wire-wrapped screen,

2. Prepacked screen,

3. Woven, mesh or premium screen.

The wire-wrapped screen is a carefully wound triangular-shaped wire with a constant gap in between successive turns. The wire is welded to vertical formers placed at $1-\mathrm{cm}$ interval around the internal diameter of the screen. Wire-wrapped screens have an advantage over prepacked screens, as they do not plug easily with drilling mud, and the plugging materials are easily removed from wire-wrapped screens as it tends to get trapped inside prepack. Wire-wrapped also has an advantage over a slotted liner, where the gap between wire-wrapped wires could be made smaller and achieve much greater precision to allow the screen to retain finer grains than the slotted liner (Markested et al. 1996).

\section{Design and screen size selection}

The first step in designing the screen is to describe the reservoir sands from samples taken from available cores and logs. These sand samples will then be tested using a laser particle size analysis (LPSA) to determine the grain size distribution, its uniformity, the range of grain sizes with indications of sorting and grain consolidation (Agunloye and Utunedi 2014; Hodge et al. 2002).

The major factors in sand screen design and selection are:

- The grain size distribution and uniformity. Figure 2 is an example of the grain size curves of sandstones from different outcrops in Brunei, which shows the cumulative amount of grain sizes.

- Choosing the proper type, strength and adequate sizing to ensure long-term and effective sand control, and avoid an unwanted situation such as total or partial plugging.

Screen permeability is also one of the important parameters in designing a screen, as it is a true indicator of inflow capacity. The standard practice is to perform sand retention tests with real or simulated formation sand. There are numerous design and performance criteria that should be considered when designing a screen. Among these criteria,
Fig. 1 Different types of standalone screens $\mathbf{a}$ and $\mathbf{b}$ premium screens with multiple layers; c wire-wrapped screen, $\mathbf{d}$ basic screen; e slotted liner and $\mathbf{f}$ prepacked screen. Photographs $\mathbf{a}$ to $\mathbf{d}$ taken and image $\mathbf{e}$ and $\mathbf{f}$ created by Jami Morteza

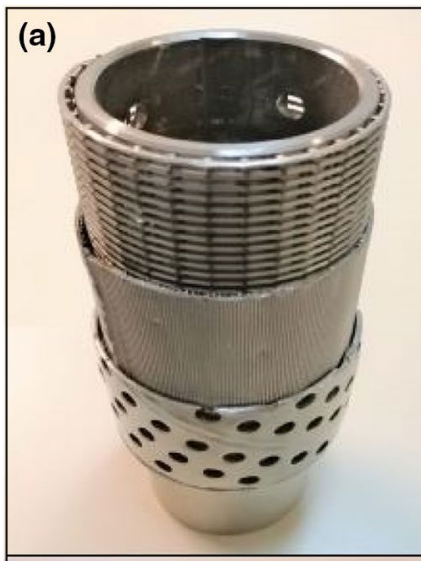

(d)
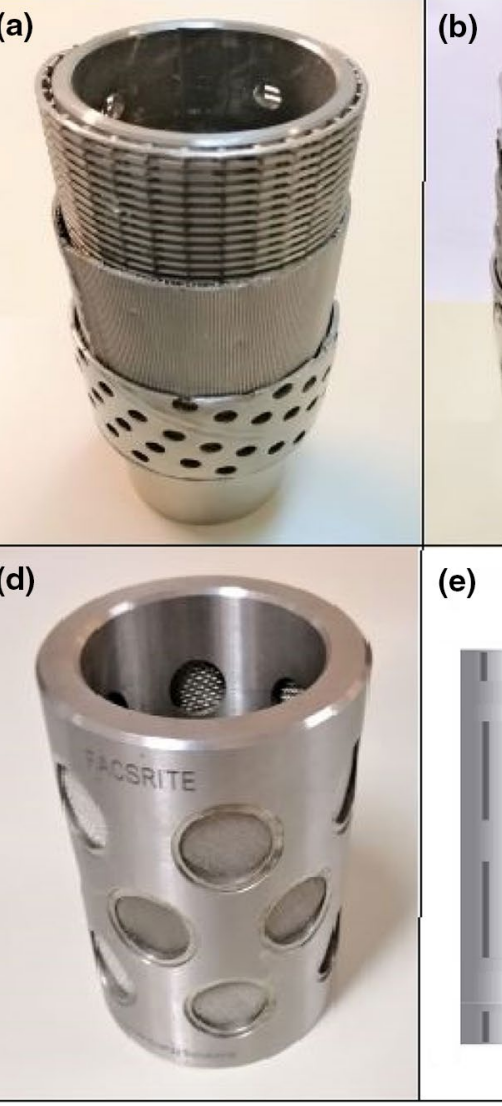

(e)

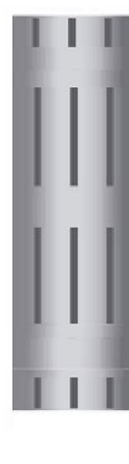

(c)

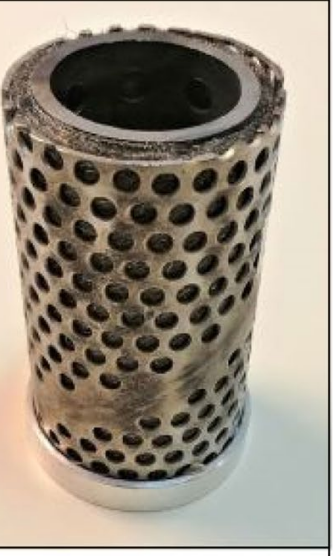

(f)

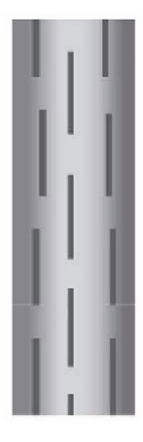


Fig. 2 PSD curves generated from grain size test of different Brunei outcrop samples (measured at UTB by Ahad Aqilah)

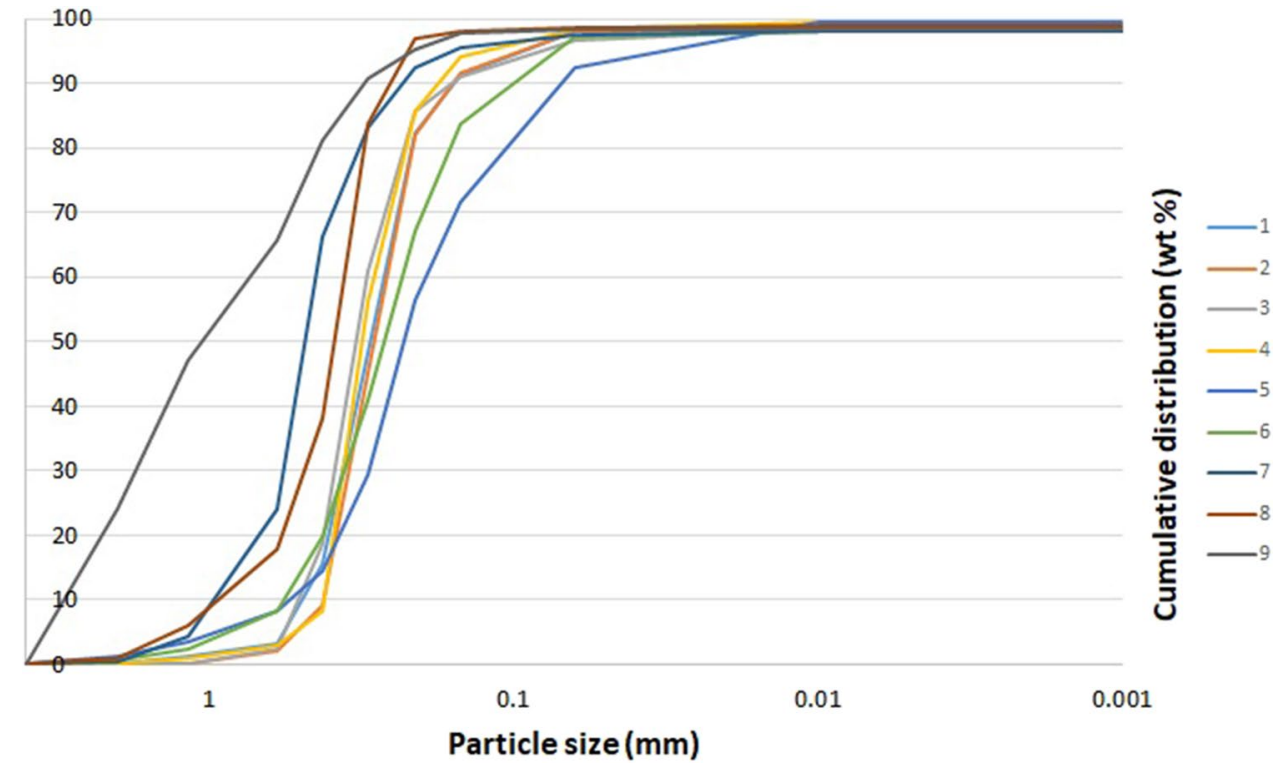

Screen retention testing (SRT)

the sand retention and plugging resistance (retained permeability) are quite important. Over the years, sizing guidelines have been developed to increase the sand control reliability under specific conditions (Hodge et al. 2002; Khamehchi et al. 2015; Parlar et al. 2016).

$\mathrm{Wu}$ et al. (2016) present some of the important screen size selection criteria which were determined from empirical correlations (Table 3) based on one or two parameters derived from the grain or particle size distribution (PSD), practical experience and laboratory retention tests.

Coberly's (1937) original screen selection criterion does not produce reliable results since it does not consider the sorting or uniformity of sands. Gillespie et al. (2000) and Ballard and Beare $(2003,2006)$ suggested alternative criteria which tend to perform better than Coberly (1937) by using sand sorting and uniformity coefficient. It is preferable to determine the sand screen opening size by testing a representative sand in a sand retention laboratory or in numerical modeling simulation.
Sand retention tests are commonly used to select the most appropriate screen to be used in sand control. Due to the problems associated with the empirical criteria, the industry-standard practice is to conduct laboratory sand retention tests on different screen coupons to determine their effective screen opening size. All tests measure pressure during the test (or flow rate if pressure is controlled) and the amount of sand produced. The process works with both reservoir sand and simulated sand. Wetting fluid, flow rate and channeling are the major factors affecting sand retention test results. Sand retention tests were useful to compare the retention performance and plugging potential of alternative screens for given formation sand (Agunloye and Utunedi 2014; Chanpura et al. 2011).

Screen performance is often evaluated based on the following two factors (Wu et al. 2016; Mondal et al. 2011; Ballard et al. 2016):
Table 3 Lists of empirical selection criterion for sand control aperture (Wu et al. 2016)

\begin{tabular}{lll}
\hline Reference & Criteria & Remarks \\
\hline Coberly (1937) & $W<1$ to $2 * \mathrm{~d} 10$ & Wire-wrapped screen or slotted liner \\
Gillespie et al. (2000) & $W<2.5 * \mathrm{~d} 50$ if $\mathrm{Uc}<6$ & Sintered weave screens \\
Gillespie et al. (2000) & $W<2 * \mathrm{~d} 50$ for somewhat & Wire-wrapped screen \\
& uniform sands & \\
Ballard and Beare $(2003,2006)$ & $W<1 * \mathrm{~d} 5$ & Dutch twill weave screens \\
Ballard and Beare $(2003,2006)$ & $W<1 * \mathrm{~d} 10$ & Sintered weave screens \\
\hline
\end{tabular}

W-slot width, d5-particle size at 5\% cumulative weight distribution, d10 - particle size at 10\% cumulative weight distribution, d50 - average particle diameter of the sample, Uc-uniformity coefficient 
- Screen plugging, as it is preferred to have a screen that can last as long as possible before plugging, and

- Sand retention, in order to achieve maximum sand retention, and do not pass a significant amount of sand through the screen.

There are two types of sand retention tests: slurry and sand-pack or prepack retention test, which will be discussed in the next section. Both of these tests are able to measure the following parameters (Mondal et al. 2011):

- Mass of sand produced as a function of time or mass of sand injected which gives some measure of a screen's sand retention efficiency

- The pressure developed across the screen and the sand pack to give some measure of screen's plugging tendency

- The particle size distribution (PSD) of the produced solids, which will help assess erosion capability.

Wu et al. (2016) reported that in the sand retention test, the sand has to be deposited onto the screen at a constant drawdown pressure, and not at a constant flow rate. This is to avoid misinterpretation of the rapid increase in the pressure profile attributed to screen plugging from a constant flow rate test. Screen plugging can be determined by measuring the permeability of the sand screen before and after the test was completed. Figure 3 shows the apparatus for the sand retention test.

There are no agreed industry standards on how sand retention should be performed or how the results are interpreted. Parameters, such as the screen permeability, amount of sand produced, and pressure drop across the screen, may be obtained from the test.

\section{Slurry test}

Slurry sand retention tests use low sand concentrations pumped through the screen to prevent segregation of the formation sand before it reaches the screen. The sand is suspended in a slurry which is a viscous polymer solution and is added to a high-flow-rate brine stream by a displacement pump to dilute the sand concentration flowing onto the screen. Figure 4a shows the experimental set up for a slurry test. Slurry tests measure the weight of solids that passed through the screen as well as the rate of pressure buildup across the screen and the amount of sand contacting the screen (Agunloye and Utunedi 2014).

\section{Sand-pack or prepack test}

In the sand-pack test, the sand is placed directly on the screen with a confining stress imposed on the sand, so the sand will be in full contact with the screen. A wetting liquid will then flow through the sand pack and the screen. This test measures the weight of sand produced as well as the pressure drop that occurred during the test. Figure $4 \mathrm{~b}$ shows the experimental setup for the sand-pack test (Agunloye and Utunedi 2014; Wu et al. 2016; Mondal et al. 2011; Chanpura et al. 2011).

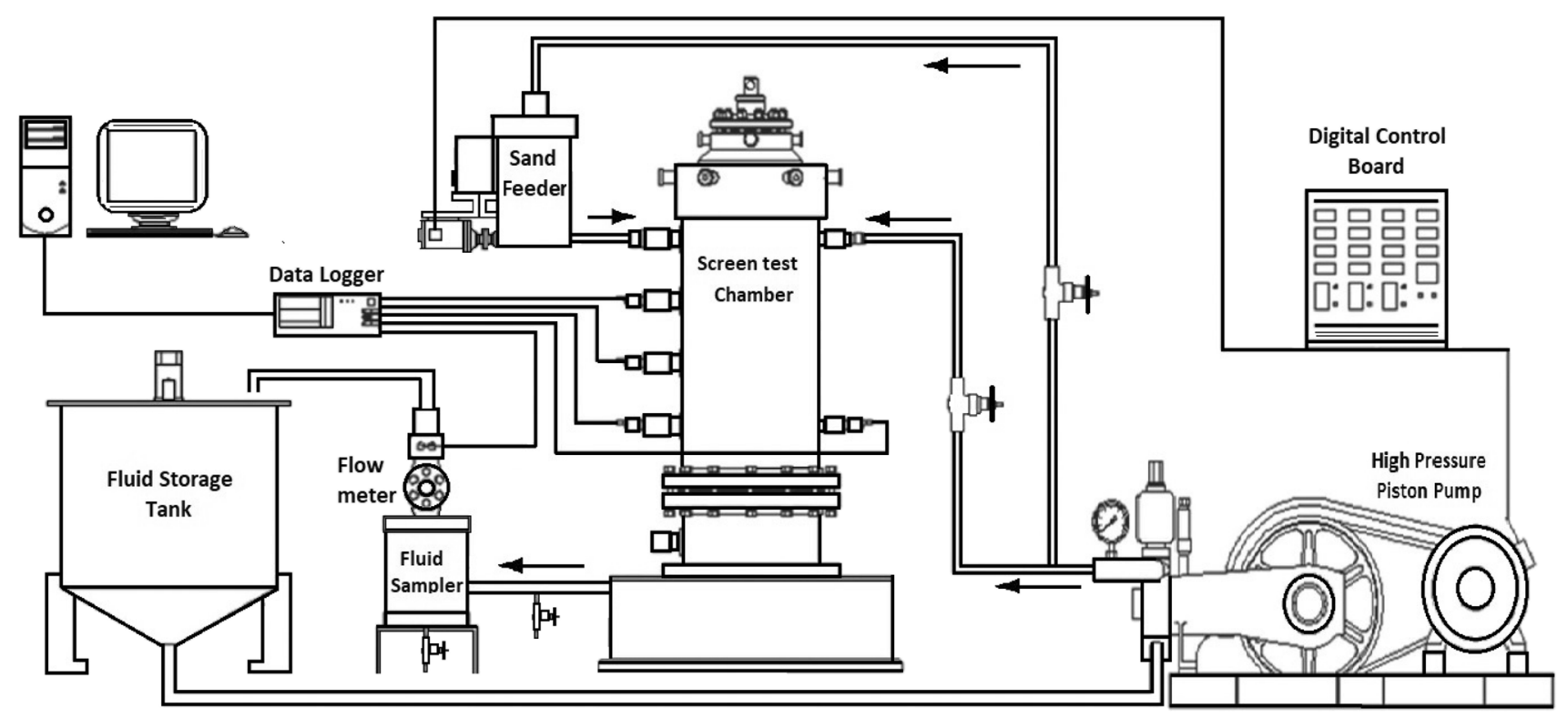

Fig. 3 Schematic diagram of a sand retention apparatus. Modified after Changyin et al. (2016) 


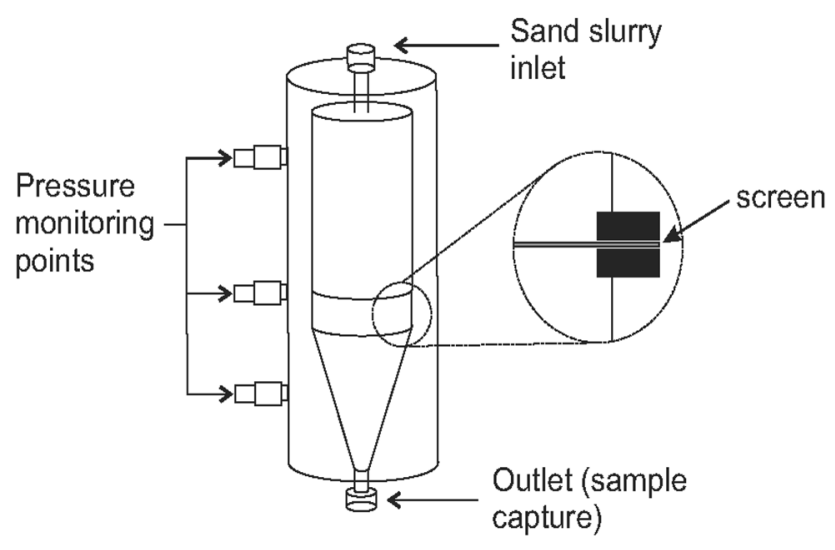

(a)

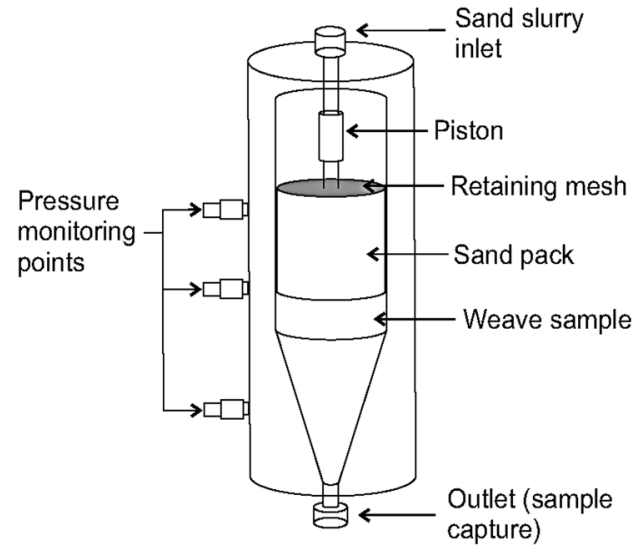

(b)

Fig. 4 Schematic diagrams of a slurry test setup, $\mathbf{b}$ sand-pack test setup. Modified after Agunloye and Utunedi (2014)

\section{Numerical modeling}

It may be expensive and time-consuming to conduct many laboratory sand retention test experiments for selecting the effective sand control method. Numerical models and software have been developed using experimental data from laboratory test. The aim of conducting numerical simulations for screen size selection is to avoid repeating laboratory tests in areas where extensive sand retention test data are available. Currently, numerical modeling does not accurately account for interactions between fluids and the particles (Agunloye and Utunedi 2014; Wu et al. 2016; Feng et al. 2012; Mondal et al. 2010; Markested et al. 1996; Constien and Skidmore 2006).

A number of the numerical models have been developed for screen size selection:

- Feng et al. (2012) developed a fully coupled numerical model by combining computational fluid dynamics (CFD) with discrete element method (DEM) code. This technique simulates the sand slurry flow and the sand retention process to determine the effect of parameters such as liquid velocity, screen slot size and particle concentration, or solid volume ratio, on sand screen performance. This approach, where DEM is used to model solid phase and CFD for fluid phase, can provide information on the interaction forces and the movement of individual particles. It could also reveal:

- The movements of entire particle size distributions,

- Retention process of sand particles by the screen,

- The degree of plugging or blockage of the screen aperture, and

- Interactions among sand particles and the screen.
- M-S method by Mondal et al. $(2010,2011)$ created a numerical simulation tool to evaluate the performance of sand screens. The simulation is based on a correlation between numbers of particles $(\mathrm{Np})$ of diameter $(\mathrm{Dp})$ produced through a screen of slot opening (W). It allows the user to estimate the mass and the size distribution of the produced solids using the entire particle size distribution of the formation sand. It is applicable to:

- Wire-wrap screens and providing more accurate predictions of screen performance and, in the absence of experimental data, can also be used as a screen selection tool.

- Square-mesh screens if the PSD (particle size distribution) of the formation sand is known.

- Markested et al. (1996) developed a numerical model to simulate plugging and sand production through a single wire-wrapped screen. It was developed to predict critical slot widths and is based on a fractal model for the particle size distribution of reservoir sands.

- Constien and Skidmore (2006) developed a method based on laboratory screens testing, which is called the performance curve or 'mastercurve' for individual screen laminates. The mastercurve could be used to predict the screen performance in well with mixtures of particle size distributions. It is constructed by measuring screen performance for produced solids and retained screen permeability versus a ratio of an effective formation size divided by the size of the screen pore opening. The aim is to reduce the amount of possible screen configuration options as well as the number of tests that are needed to make selection decisions. 


\section{Alternative to stand-alone sand control}

Parlar et al. (2016) suggest a number of reasons why SAS completion may be inappropriate for sand control:

1. Screen opening too small to manufacture

2. The formation sand retention screen is susceptible to plugging during installation which increases the completion cost or complexity beyond the gravel packing.

3. The project is intolerant to any transient sand production.

4. The formation is highly laminated with moveable shale streaks that are difficult to isolate with annular packers

5. The formation has enough strength that at producing conditions the wellbore will not fail immediately.

If stand-alone sand screen is not suitable for sand control, then the next option is usually to consider gravel packing to the reservoir.

\section{Gravel packing}

Gravel pack was developed in the early 1990s in response to an increasing number of failures of the traditional standalone sand screen completions. The driving force for applying openhole gravel packs (OHGPs) in deepwater wells was to safeguard long-term productivity of the well by minimizing screen plugging, which may result in productivity decline and creation of localized areas of high-velocity flow (production hot spots) in non-plugged parts of the screen. However, these factors are equally valid for onshore wells that need to be completed with sand control in relatively long, highly deviated reservoir sections (Vliet et al. 2001).

In gravel packing, sand production can be controlled by careful selection of gravel size considering the formation sand size. The main factor that influences the sand production in gravel packed wells is the flow restriction caused by the gravel pack itself. There are three important parameters in designing and investigation of gravel packed wells that influence gravel pack permeability and cost (Khamehchi et al. 2015; Deghani 2010):

- Selection of gravel size or mesh size to stop the movement of formation sand,

- Determination of gravel pack length or penetration of gravel in formation,

- Placement of gravel, ideally in a tight pack that has a radius as large as possible

The ideal size of gravel pack sand can be determined from LPSA or sieve analysis from core samples, or bailed samples which tend to be large, or produced samples which tend to be small, which are sized to achieve a suitable grain size ratio. In a gravel pack completion, a screen is used with the gravel pack to prevent the gravel from moving. The common type of screen in the gravel pack is wire-wrap screen. Screen openings should not be larger than the smallest gravel diameter. Three basic tools are used in gravel packing operations:

1. Packer or crossover tool assembly

2. Over-top tool assembly

3. Port collars

Deghani (2010) has listed the basic gravel pack processes, which are presented in Table 4.

\section{Discussions and limitations of screen retention tests}

\section{Limitations on the sand retention test}

When reservoir sand is not available, commercial sand can be made with a matching particle size distribution to the reservoir sand, using either commercially quarried outcrop sands or ground silica, or a mixture of both. These types of sand are generally well sorted with narrow size distributions. Ground silica is used to represent the fines in reservoir rocks, and as well as any inaccuracies in the representation of the reservoir sand, the simulated sand will comprise silica only. Ballard et al. (2016) state that using simulated sand could be difficult in the sand retention test because the reservoir sand production can be highly variable, and a much slower fluid flow velocity could cause uncertainties.

Limitations that have been identified by Chanpura et al. (2011) and Agunloye and Utunedi (2014) from sand retention tests include

- A screen with a retained permeability greater than $50 \%$ of the original screen permeability is acceptable

- The screen was selected based on the relative performance of screen candidates

- The screen was considered plugged when the pressure difference across sand pack and screen was greater than 100 psi (0.7 MPa)

- Tests were stopped at a low pressure limit, long before either solid production stops or stabilizes.

- Parameters such as the pressure or flow rate used in the system are generally controlled and tend to be one or two magnitudes higher than the field parameters. This could exaggerate the screen performance that might not exist.

Chanpura et al. (2011) also pointed out that the sand produced from sand retention tests cannot be directly used to make quantitative predictions of sand production under field conditions unless the test procedures include the maximum

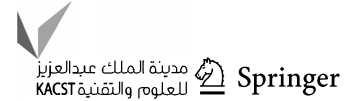


Table 4 Types of gravel packs (Deghani 2010)

\begin{tabular}{ll}
\hline Types of gravel pack & Brief description \\
\hline $\begin{array}{l}\text { Openhole gravel pack (OHGP, sometimes referred to as internal gravel } \\
\text { pack, IGP) }\end{array}$ & $\begin{array}{l}\text { Commonly installed in vertical wells } \\
\text { Easiest type of gravel pack } \\
\text { Less expensive than other types of gravel packs }\end{array}$ \\
$\begin{array}{l}\text { Hole stability, screen plugging and thief zones can be a problem } \\
\text { Limited to bottom interval in multiple-zone completions } \\
\text { Combination of fracture treatment and annular gravel pack }\end{array}$ \\
$\begin{array}{ll}\text { Creates wide fracture extending through the near-wellbore zone } \\
\text { Could prevent from making contact with unwanted zones }\end{array}$ \\
$\begin{array}{l}\text { Used where sands are laminated } \\
\text { High rate water pack }\end{array}$ \\
$\begin{array}{l}\text { Pumps water and sand at high rates to create short fractures } \\
\text { Maximizes gravel placement in the perforations } \\
\text { Typically used in completion near water or gas contacts }\end{array}$ \\
$\begin{array}{l}\text { It is important to define the allowable pump operating ranges } \\
\text { Pump rate used must be high enough to exceed the rate of fluid } \\
\text { loss to push the dunes of gravel (alpha wave) to the end of the } \\
\text { screen } \\
\text { Uses small-diameter tubes along the outside of the screen that } \\
\text { allows gravel to be pumped at high velocities. } \\
\text { A controlled viscosity fluid is used to suspend gravel and aid its } \\
\text { transport }\end{array}$ \\
\hline
\end{tabular}

laboratory-measured sand production rates and maximum impairment values.

\section{Reservoir or simulated sands}

Ballard et al. (2016) conducted sand retention tests on two reservoir sands (B77 and M1) along with their simulated version. M1 sand is better sorted than B77 sand to determine the differences between using reservoir sand and simulated sand on wire-wrapped and metal mesh screen in sand retention tests. The PSDs created for the simulated sands matched the respective reservoir sands. During sand retention tests, both versions of sand gave different retention results, despite having similar grain size distributions. The authors noted:

- On slurry tests, both B77 and M-1 reservoir sands were poorly retained on wire-wrapped screen and yield better retention on metal mesh screen than its simulated sands.

- On sand-pack tests, both B77 and M-1 reservoir sands were better retained on both wire-wrapped and metal mesh screens than the simulated sands.

This may be explained by the particle shape. The simulated sand is made with well-rounded particles composed entirely of silica, but reservoir sands contain a variety of minerals, which affect the grain shape and its properties. The authors pointed out that these observations may not be widely applicable as they considered only two types of sand in their tests, though they suggest that reservoir sand should be used whenever possible (Ballard et al. 2016).

\section{New test apparatus introduced}

Chen et al. (2016) developed a new test apparatus to offer more accurate screen performance evaluation. They concerned that the current laboratory tests use a small screen disk, due to its convenience and low cost. The current test methods can only test the minimal opening size and pressure drop of local screen material and could not effectively reflect the performance of an integrated screen pipe run in the wellbore.

Instead of using small disks, they used full-size screen samples (Fig. 5). In their method, different types of full-size screens were tested using sand samples from target reservoirs. The results were then compared with the results from the cut small disks mainly from the plots of the particle size distribution of screen and pressure drop across the screen sample. They concluded that the small disks sample can only reflect performances of local sand retention material.

\section{Sandstone properties of Brunei reservoirs}

This section will review Brunei reservoirs that produce sand. Brunei's major onshore and offshore fields are situated within the Neogene Baram, Champion and Meligan Deltas and Northwest Borneo along the South China Sea. These deltaic fluvio-marine sediments are composed of several sandstone reservoirs vertically stacked with thin layers of laterally continuous shales as cap rocks. Anglo Saxon Petroleum Co. drilled the Belait-2 well which struck the first oil in Brunei in 1914. Since then, many wells have been 


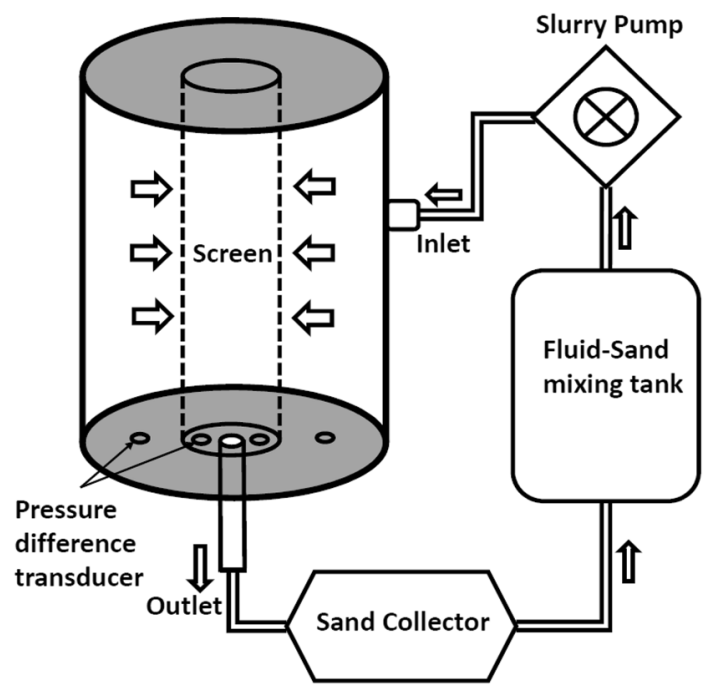

Fig. 5 Schematic diagram of the full-screen test apparatus which can replace the screen test chamber in Fig. 2. Modified after Changyin et al. (2016)

drilled and several onshore and offshore fields have been developed. These are poorly consolidated sandstone reservoirs, and many of the wells have experienced sand production. To mitigate the impact of sand production, many wells were completed with internal gravel packing as the preferred method of sand control (Fourie et al. 2013; Saeby et al. 2001).

\section{Champion field}

In 1998, Brunei Shell Petroleum (BSP) decided to redevelop a number of reservoir blocks located in the southeastern part of the Champion field. The reservoirs involved were relatively shallow ( $<1100 \mathrm{mTVD})$, with shaly, laminated and unconsolidated sandstone. These reservoirs were to be developed by drilling highly deviated wells, and sand control was to be installed in the producing reservoirs. Due to problems during SAS installation on these deviated wells, BSP decided to install openhole gravel pack (Vliet et al. 2001).

After installing OHGPs, the following production challenges were recognized:

- The small difference between pore and fracture pressure,

- The length of the reservoir sections planned to be gravel packed was more than $1000 \mathrm{~m}$,

- The presence of faults and fractures and associated risk of heavy fluid losses.

Champion West (CW) is located at $7 \mathrm{~km} \mathrm{NNW}$ of the Champion main field offshore Brunei and has been producing since 1975. This field was developed without considering sand production because the reservoirs were located at higher depth known as the sand production cut-off depth with relatively consolidated rock formation. At that time, the expandable sand screen (ESS) was a new and unproven technology. Three wells were completed with ESS and one well (CW-12) with an internal gravel pack (IGP) for comparison. ESS was considered as a good alternative to gravel packing because of the lower cost, the ease of operation, logistic simplicity and completion flexibility. ESS could expand to eliminate the annulus and make gravel packing operations unnecessary in reservoirs with reactive shale, low fracture gradient, or fractures and faults (Saeby et al. 2001; Lau et al. 2004).

Reservoirs in the Champion field are relatively consolidated sandstones with low risk of major sand failure, but due to expected transient failure during high drawdown and depletion all wells have been completed with either IGP and ESS. Based on Table 5, the CW-12 well was completed with conventional acid prepacked IGP with PI of $15-25 \mathrm{~m}^{3} / \mathrm{d} / \mathrm{bar}$ and skin of 15. Meanwhile, the production data of CW-13, 14 and 15 with ESS completion show higher productivity. CW-15 was tested and showed high productivity and low skin $\left(Q=800 \mathrm{~m} 3 / \mathrm{d}, \mathrm{PI}=40 \mathrm{~m}^{3} / \mathrm{d} /\right.$ bar, skin =5). $\mathrm{CW}-13$ and $14 \mathrm{ESS}$ completions showed the PI in the range of $25-50 \mathrm{~m}^{3} / \mathrm{d} /$ bar. In the initial stages of production, no sand or water has been observed (Saeby et al.2001).

\section{South West Ampa field}

South West Ampa (SWA) field is located $10 \mathrm{~km}$ offshore Brunei Darussalam. The initial discovery was made in 1963 with SWA-1 which showed a shallow reservoir with API gravity of $40^{\circ}$, initial oil viscosity of $0.35 \mathrm{cp}$ with relatively high solution gas-oil ratio and variable condensate content. SWA field consists of many thin stacked sand layers, with a history of sand production. The shale stability issues and multiple sand layers made the sand control completions challenging. Several openhole gravel packs were installed in the field and were unsuccessful due to the collapse of shale once the openhole was displaced to brine. Consequently, ESS was chosen as the sand control method to replace gravel packing and was first installed in SWA-290 well (Lau et al. 2004).

Results show that ESS was successfully run and expanded $543 \mathrm{~m}$ of 4" ESS strings and expanded into a 6" horizontal reservoir section. Prior to running the ESS, the mud was further conditioned over 325 mesh screens to reduce the particle size in the mud for running and expanding the screens. Similar 4" ESS was successfully run in Champion Field, CP-306 (Lau et al. 2004).

\section{Egret field}

The Egret field is located $43 \mathrm{~km}$ offshore in $60 \mathrm{~m}$ water depth. The field consists of stacked sandstone formations in

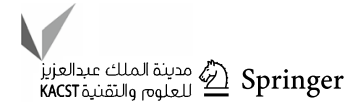


Table 5 Champion West wells data (Saeby et al. 2001)

\begin{tabular}{lllll}
\hline & CW-12 & CW-13 & CW-14 & CW-15 \\
\hline Max deviation $\left(^{\circ}\right)$ & 56.5 & 63.1 & 65.3 & 54.3 \\
Well depth (m) & 3244 & 4463 & 4444 & 3240 \\
Mud type & TAME/Palm Oil & PETROFREE & PETROFREE & TAME/PalmOil \\
Completion brine & $2 \% \mathrm{KCl} / \mathrm{NaCl}$ & $2 \% \mathrm{KCl} / \mathrm{NaCl}$ & $\mathrm{CaCl}_{2}$ & $2 \% \mathrm{KCl} / \mathrm{NaCl}$ \\
Zones (total/with-sand-control) & $4 / 2$ & $4 / 4$ & $5 / 1$ & $3 / 3$ \\
Top-bottom perforations (m) & $2650 / 3190$ & $3160 / 3835$ & $2692 / 4393$ & $2782 / 3195$ \\
Net perforation (m) & 230 & 214 & 303 & 108 \\
Sand control & $2 \times$ single IGP & $1 \times$ triple ESS & $1 \times$ single ESS & $1 \times$ dual ESS \\
& & $1 \times$ single ESS & & $1 \times$ single ESS \\
Screen type & IGP & ESS & ESS & ESS \\
Screen size & $4 "$ & $4 " \& 4.5 "$ & $4.5 "$ & $4 "$ \\
Initial production pi (m $\left.{ }^{3} / \mathrm{d} / \mathrm{bar}\right)$ & 25 & $25-50$ & $25-50$ & 40 \\
Skin & 15 & - & - & 5 \\
Total screen length (m) & 152 & 315 & 116 & 174 \\
\hline
\end{tabular}

TAME thermally activated mud emulsion mainly gas and some oil-rim reservoirs. The first production was from three gas wells in 2003. Two of the three gas wells, EG-1A and EG-1B, needed sand control, and a combination of hydraulic fracturing and ESS was selected. The combined technologies were a key factor in achieving the desired product performance. After the sand control was installed, the tendency for the screen to get plugged was minimized and the sand production was successfully controlled with a low skin factor. The fines production from the Egret field was also successfully mitigated, with no production decline observed (Abdul-Rahman et al. 2006).

\section{Current situation}

This section lists down some of the sand control that is recently installed in different reservoirs around the world. They are:

- Zeidan et al. (2018) investigated a reservoir called Lower Fars from Umm Niqa field in north Kuwait. This field has been successfully completed with vertical cased SAS despite being in a challenging environment with unconsolidated, sub-hydrostatic-sand and a highly sour and moderately corrosive environment. The reservoir was originally planned to be completed with a gravel pack because of the PSD result of the sand showing high Uc of about $7.5 \%$ and $11 \%$ of fine sands. This plan was then challenged by the author, and it was decided to complete the reservoir using Halliburton's PoroMax SAS (vertical cased SAS). The decision was made based on a thorough analysis of the formation sand, the design of the screen as well as the completion fluid during SAS installation.

- Daramola and Alinnor (2018) present remedial sand control for a low-permeability sandstone reservoir. The field was an oil field located offshore Nigeria. Between 2014 and 2016, four wells failed due to multiple sanding events, unstable production rates and platform trips. Further investigations of the bottom-hole pressure data showed that three wells, A1, A2 and A3, failed due to high pressure drawdown, leading to screen breakage, and sand bridge in tubing. A4 well failed either due to the tubing restriction, screen breakage, sand bridge in tubing or scale formation buildup. The asset team decided to design and install frac-pack completion to improve sand control. Frac pack was selected because it has better durability for wells with high pressure drawdown.

- Ojeh-Oziegbe et al. (2019) describe the successful installation of a single-trip stand-alone screens completion (STC-SAS) in Bonga deepwater reservoir. Bonga field is located in the southwest of Warri, on the continental slope of the Niger Delta. Due to the declining oil price, the main reason for using STC-SAS was that it could reduce the rig completions time by about $50 \%$ compared to the conventional multiple trip SAS completions, hence saving operation costs.

- Openhole gravel packs (OHGPs) with a predrilled liner have been successfully installed in 4 wells in the Raven field as reported in Tahirov et al. (2019). Raven field is located in Egypt and is high-pressure high-temperature (HPHT) gas field with a reservoir pressure of over 10,700 psi and reservoir temperature around $141{ }^{\circ} \mathrm{C}\left(285^{\circ} \mathrm{F}\right)$. The reservoir contains stacked channel formation and requires sand control completion to sustain long-term gas production. All 4 wells showed good performance results with very low skin numbers $(+1.5$ to +5$)$.

- Mahakam River delta is located in the East Kalimantan Province of Borneo, Indonesia. It consists of a large gas field (Tunu) and an oil filed (Handil), where the primary 
targets located in the shallow, unconsolidated reservoir sands. The gross interval that requires sand control was believed to be more than $1000 \mathrm{~m}$ long. To save rig time to complete the wells with long multilayer intervals, multizone single-trip gravel pack (MZ-STGP) completion was selected to maximize oil and gas recovery. To date, more than 650 zones have been successfully installed with MZ-STGP (Muryanto et al. (2018).

\section{Conclusions}

Sand production is controlled by four major factors: reservoir rock properties (lithological, chemistry and mechanical), fluid properties (fluid phases and chemistry, water invasion), pressure regime (production strategy) and secondary interventions such as water or chemical flooding. A better understanding of the impact of these factors for a given reservoir can significantly improve the effectiveness of sand production mitigation strategies.

Various methods of sand control are available including slotted liner, wire-wrapped screen, prepacked screen, shrouded metal mesh screen, expandable screen, in situ consolidation (resin), oriented and selective perforation, openhole and cased-hole gravel pack, frac pack and screenless frac pack. Each method has associated risks such as installation difficulty, cost, level of fines production, impact on well productivity and longevity. It is essential to determine the reservoir and well parameters such as rock strength, grain size distribution, lithological variations, well type and completion, surface facilities tolerance before selecting the sand control method.

Stand-alone sand screens are of low cost, reliable and simple, with relatively good long-term productivity particularly for highly deviated or horizontal openhole completions. If stand-alone screens are to be used, standard experimental screen retention tests will usually be run to determine the most appropriate screen for a given set of conditions; typically for a well in particular location in a reservoir with a known fluid composition and pressure. The limitation of such tests is that they usually do not test the behavior of the screen over the full range of operating parameters. A rigorous screen selection procedure, based on reservoir's grain size distribution, is essential to choose the best screen for a given reservoir.

Openhole and cased-hole gravel packs are effective alternatives to stand-alone screens. These packs minimize the sand production with the selection of appropriate sized gravel for the produced formation sand. Gravel packs are generally designed for long-term productivity of the well and are expensive and require larger-diameter holes to install.

Screen permeability and the associated sand retention and plugging resistance are indicators of inflow capacity which are important parameters in screen selection that can be determined from screen retention tests. The standard practice is to perform these tests with either real or simulated formation sand. There are two main types of sand retention test: slurry and sand-pack or prepack retention test. Both of these can measure the mass of sand produced as a function of time, the pressure developed around the screen and the particle size distribution of the produced sand.

The recent development of numerical simulation techniques may provide an approach to solving the general problem of screen selection for different grain shapes and size distributions, different fluids and different pressures, once these simulations have been calibrated with experimental tests. They may also suggest improvements to experimental techniques to allow the investigation of the behavior of stand-alone screens, expandable screens and gravel packs over a range of reservoir parameters encountered during the life of the field.

The unconsolidated sands from Brunei's deltaic and fluvio-deltaic reservoir sandstones are vertically stacked with thin layers of laterally continuous shales as cap rocks. These reservoirs have encountered significant sand production issues, so most offshore and onshore wells have been completed with stand-alone screens, expandable sand screens or openhole gravel packs. The expandable and standalone screens have had limited success in particular areas. Openhole gravel packs have been outperforming the screens, maintaining permeability across the screen, retaining sand effectively and showing a long-term resistance to plugging.

Open Access This article is licensed under a Creative Commons Attribution 4.0 International License, which permits use, sharing, adaptation, distribution and reproduction in any medium or format, as long as you give appropriate credit to the original author(s) and the source, provide a link to the Creative Commons licence, and indicate if changes were made. The images or other third party material in this article are included in the article's Creative Commons licence, unless indicated otherwise in a credit line to the material. If material is not included in the article's Creative Commons licence and your intended use is not permitted by statutory regulation or exceeds the permitted use, you will need to obtain permission directly from the copyright holder. To view a copy of this licence, visit http://creativecommons.org/licenses/by/4.0/.

\section{References}

Abdul-Rahman S, Lim D, Lim J, Ong K (2006) Innovative use of expandable sand screens combined with propped hydraulic fracturing technology in two wells with intelligent completions in egret field, Brunei. In: SPE Asia Pacific oil \& gas conference and exhibition. Society of petroleum engineers

Agunloye E, Utunedi E (2014) Optimizing sand control design using sand screen retention testing. In: SPE Nigeria annual international conference and exhibition. Society of petroleum engineers

Ballard T, Beare S (2003) Media sizing for premium sand screens: dutch twill weaves. In: SPE European formation damage conference. Society of Petroleum Engineering 
Ballard T, Beare S (2006) Sand retention testing: the more you do, the worse it gets. In: SPE international symposium and exhibition on formation damage control. Society of petroleum engineers

Ballard T, Beare S, Wigg N (2016) Sand retention testing: reservoir sand or simulated sand-Does it matter? In: SPE international conference $\&$ exhibition on formation damage control. Society of petroleum engineers

Changyin D, Qinghua Z, Kaige G, Kangmin Y, Xingwu F, Chong Z (2016) Screen sand retaining precision optimization experiment and a new empirical design model. Pet Explor Dev 43(6):1082-1088

Chanpura RA, Hodge RM, Andrews JS, Toffanin EP, Moen T, Parlar M (2011) A review of screen selection for standaloe applications and a new methodology. SPE Drilling Completion 26:84-95

Chen Y, Wang S, Deng G, Chen Z, Zhang J, Li W (2016) A new test apparatus for evaluating premium screen performance. Adv Pet Explor Dev 11(1):30-34

Coberly C (1937) Selection of screen openings for unconsolidated sands. API Drilling and production practice. American Petroleum Institute, New York, pp 189-201

Constien VG, Skidmore V (2006) Standalone screen selection using performance mastercurves. In: SPE international symposium and exhibition on formation damage control. Society of petroleum engineers

Daramola B, Alinnor C (2018) Optimising sand control and production strategies in a low permeability sandstone oil field. In: SPE international conference and exhibition on formation damage control. Society of petroleum engineers

Deghani M (2010) Oil well sand production control. In: The 1st international applied geological congress. Islamic Azad University, Iran

Feng Y, Choi X, Wu B, Wong C (2012). Evaluation of sand screen performance using a discrete element model. In: SPE Asia Pacific oil and gas conference and exhibition. Society of petroleum engineers

Fourie B, Marpaung B, Jansen R, Wong A, Mok D, Karlsey N (2013) First installations of the 9-5/8-in. enhanced single trip multi-zone sand control technology in Offshore Brunei. In: IPTC 2013: international petroleum technology conference

Gillespie G, Deem C, Malbrel C (2000) Screen selection for sand control based on laboratory. In: SPE Asia Pacific oil and gas conference and exhibition. Society of petroleum engineers

Gupta A, Kamat D, Zulkapli M, Borhan N, Kobbeltvedt A, Hammersmark J, Sam A (2016) An alternate sand handling technology for efficient sand management: pilot and way forward. In: Offshore technology conference Asia. Offshore Technology Conference

Hodge RM, Burton RC, Constien V, Skidmore V (2002) An evaluation method for screen-only and gravel-pack completions. In: International symposium and exhibition on formation damage control. Society of petroleum engineers

Ikporo B, Sylvester O (2015) Effect of sand invasion on oil well production: a case study of garon field in the Niger Delta. Int J Eng Sci (IJES) 4(5):64-72

Khamehchi E, Reisi E (2015) Sand production prediction using ratio of shear modulus to bulk compressibility (case study). Egyptian J Pet 24(2):113-118

Khamehchi E, Ameri O, Alizadeh A (2015) Choosing an optimum sand control method. Egyptian J Pet 24(2):193-202

King GE (2013) Sand control methods. Retrieved from https://www. yumpu.com/en/document/read/6184334/sand-control-methodsgeorge-e-king-engineering

Lau H, Vliet J, Morin D, Ward M, Djamil A, Kuhnert P, Shanks S (2004) Openhole expandable-sand-screen completions. SPE Drilling \& Completion 01(19):46-51

Markested P, Christie O, Rorvik O, Espedal A (1996) Selection of screen slot width to prevent plugging and sand production. In: SPE formation damage control symposium. Society of petroleum engineers
Matanovic D, Cikes M, Moslavac B (2012) Sand control in well construction and operation. Springer, Berlin

Mondal S, Sharma MM, Chanpura R, Parlar M, Ayoub JA (2010) Numerical simulations of screen performance in standalone screen applications for sand control. In: SPE annual technical conference and exhibition. Society of petroleum engineers

Mondal S, Sharma M, Hodge R, Chanpura R, Parlar M, Ayoub J (2011) A new method for the design and selection of premium/woven sand screens. In: SPE annual technical conference and exhibition. Society of petroleum engineers

Muryanto B, Fransiskus W, Wijaya R, Styward B, Ji Y, Albertson E, Widyastuti A (2018) Applications of a multizone single-trip gravelpack system in developing a shallow-gas field. In: Offshore technology conference Asia. Offshore Technology Conference

Ojeh-Oziegbe O, Olatunji I, Alawode O, Walker J, Murdoch E, Patel D, Aye Y (2019) Successful installation of the first deep water single trip stand-alone screens in the industry saves rig time on bonga project. In: Offshore Technology Conference. Offshore Technology Conference

Ott WK (2008) Selection and design criteria for sand control screens. SPE 120505-DL, SPE Distinguished Lecture and Presentation During 2007-2008

Parlar M, Tibbles RJ, Gadiyar B, Stamm B (2016) A new approach for selecting sand-control technique in horizontal openhole completions. SPE Drilling \& Completion 31(01):4-15

Penberthy W, Shaughnessy C (1992) Sand control. Henry L. Doherty Memorial Fund of AIME, Society of petroleum engineers

Roberts A (2014) Geotechnology: an introductory text for students and engineers. Elsevier, Amsterdam

Saeby J, Lange F, Aitken S, Aldaz W (2001) The use of expandable sand-control technology as a step change for multiple-zone smart well completion - a case study. In: SPE Asia Pacific oil and gas conference and exhibition. Society of petroleum engineers

Suman GO, Ellis RC, Snyder RE (1991) Sand control handbook: prevent production losses and avoid well damage with these latest fieldproven techniques. Gulf Publishing Company, Houston, Texas

Tahirov T, El-Wakeel W, Mohiuldin G, Whaley K, Jackson P, Olinger M, Elshafaie I (2019) Sand control completions for raven field in Egypt. In: Offshore technology conference

Toelsie S, Prediepkoemar G (2013) Sand control in shallow unconsolidated sandstone oil reservoirs at staatsolie NV suriname. In: SPE European formation damage conference \& exhbition. Society of petroleum engineers

Vliet J, Lau H, Skilbrei O, Rahman S (2001) Horizontal openhole gravel packs boost oil production in Brunei. In: SPE Asia Pacific improved oil recovery conference. Society of petroleum engineers

Wan R, Wang J (2004) Analysis of sand production in unconsolidated oil sand using a coupled erosional-stress-deformation model. J Can Pet Technol. https://doi.org/10.2118/2001-049

Wu B, Choi S, Feng Y, Denke R, Barton T, Wong C, Madon B (2016) Evaluating sand screen performance using improved sand retention test and numerical modelling. In: Offshore technology conference Asia. Offshore Technology Conference

Zeidan A, Al-Bader H, Pandey C, Al-Ibrahim A, Ayyavoo M, Al-Ateeq A, Bosilca D (2018) Successful installation of stand alone screen in challenging environment in Umm Niqa Field. In: SPE international heavy oil conference and exhibition. Society of petroleum engineers

Publisher's Note Springer Nature remains neutral with regard to jurisdictional claims in published maps and institutional affiliations. 